\title{
Conformational changes and translocation of tissue-transglutaminase to the plasma membranes: role in cancer cell migration
}

\author{
Ambrish Kumar ${ }^{1}$, Jianjun Hu², Holly A LaVoie ${ }^{3}$, Kenneth B Walsh' ${ }^{4}$, Donald J DiPette ${ }^{5}$ and Ugra S Singh ${ }^{* *}$
}

\begin{abstract}
Background: Tissue-transglutaminase (TG2), a dual function G-protein, plays key roles in cell differentiation and migration. In our previous studies we reported the mechanism of TG2-induced cell differentiation. In present study, we explored the mechanism of how TG2 may be involved in cell migration.

Methods: To study the mechanism of TG2-mediated cell migration, we used neuroblastoma cells (SH-SY5Y) which do not express TG2, neuroblastoma cells expressing exogenous TG2 $\left(\mathrm{SHY}_{\mathrm{TG} 2}\right)$, and pancreatic cancer cells which express high levels of endogenous TG2. Resveratrol, a natural compound previously shown to inhibit neuroblastoma and pancreatic cancer in the animal models, was utilized to investigate the role of TG2 in cancer cell migration. Immunofluorescence assays were employed to detect expression and intracellular localization of TG2, and calcium levels in the migrating cells. Native gel electrophoresis was performed to analyze resveratrol-induced cellular distribution and conformational states of TG2 in migrating cells. Data are presented as the mean and standard deviation of at least 3 independent experiments. Comparisons were made among groups using one-way ANOVA followed by Tukey-Kramer ad hoc test.
\end{abstract}

Results: TG2 containing cells ( $\mathrm{SHY}_{\mathrm{TG} 2}$ and pancreatic cancer cells) exhibit increased cell migration and invasion in collagen-coated and matrigel-coated transwell plate assays, respectively. Resveratrol (1 $\mu \mathrm{M}-10 \mu \mathrm{M})$ prevented migration of TG2-expressing cells. During the course of migration, resveratrol increased the immunoreactivity of TG2 without affecting the total TG2 protein level in migrating cells. In these cells, resveratrol increased calcium levels, and depletion of intracellular calcium by a calcium chelator, BAPTA, attenuated resveratrol-enhanced TG2 immunoreactivity. In native-polyacrylamide gels, we detected an additional TG2 protein band with slower migration in total cell lysates of resveratrol treated cells. This TG2 form is non-phosphorylated, exclusively present in plasma membrane fractions and sensitive to intracellular $\mathrm{Ca}^{2+}$ concentration suggesting a calcium requirement in TG2-regulated cell migration.

Conclusions: Taken together, we conclude that resveratrol induces conformational changes in TG2, and that $\mathrm{Ca}^{2+}$-mediated TG2 association with the plasma membrane is responsible for the inhibitory effects of resveratrol on cell migration.

Keywords: Cell migration, Invasion, Neuroblastoma, Resveratrol, Tissue-transglutaminase

\footnotetext{
* Correspondence: Ugra.Singh@uscmed.sc.edu

'Department of Pathology, Microbiology and Immunology, School of

Medicine, University of South Carolina, Columbia, SC 29209, USA

Full list of author information is available at the end of the article
} 


\section{Background}

Tissue-transglutaminase (TG2) possesses $\mathrm{Ca}^{2+}$-dependent transamidation activity by which it catalyzes the crosslinking of proteins via the formation of proteolytically resistant $\varepsilon$ - $(\gamma$-glutamyl) lysine isopeptide bonds between the glutamine residue of one protein and the lysine residue of another protein, polyamine, or monoamine [1-3]. In addition, TG2 acts as a G-protein with GTP-binding and hydrolyzing activity which regulates transamidation function $[4,5]$. In the extracellular matrix (ECM), TG2 mediates cell-ECM interactions through fibronectin and integrins [6,7] and promotes cell attachment, migration and invasion $[8,9]$. When TG2 is present at the plasma membrane, it acts as a G-protein and participates in $\alpha 1$ adrenergic signaling [4].

Depending upon the cell type and cellular distribution, TG2 is physiologically involved in cell differentiation, cell death, migration, invasion or survival $[10,11]$. The increased cellular level of TG2 contributes to the development of drug resistance and metastatic phenotype in several cancer cell types such as that of pancreatic cancer [12], ovarian cancer cells [13,14], breast cancer [15], glioblastoma and malignant melanoma [16]. Studies carried out in an ovarian cancer xenograft model [17] and in mammary epithelial cell lines [18] indicated a direct correlation of TG2 with cancer cell invasion and tumor metastasis. The suppression of TG2 expression, using a TG2 inhibitor or siRNA, induces apoptosis in pancreatic cancer tissue [19]. Moreover, increased level of TG2 by epidermal growth factor (EGF) treatment protects cancer cells from doxorubicin-induced apoptosis highlighting the role of TG2 in cancer cell survival [20]. In our previous studies we reported that TG2 plays a key role in retinoic acid-induced cell differentiation [21,22]. However, the mechanism underlying tissue-transglutaminase mediated cell migration is not well known.

In the present study, using neuroblastoma wild type SH-SY5Y cells, SH-SY5Y cells with overexpressing TG2 $\left(\mathrm{SHY}_{\mathrm{TG} 2}\right)$ and pancreatic cancer cells (which express higher basal TG2), we have demonstrated that TG2 promotes both cell migration and invasion. To address the molecular mechanism(s) involved in TG2-mediated cancer cell migration, we used a polyphenolic compound, resveratrol (3,5,4'-trihydroxystilbene) which is found in red grapes and blueberries and has shown promising results in the treatment of neuroblastoma and other cancers. However, high concentrations of resveratrol were used in these studies and were focused on resveratrol-induced cell death and the underlying signaling mechanisms [23-27]. The goal of our study was to determine if resveratrol at lower concentrations affects cancer cell migration and invasion and whether it targets TG2 to modify endpoints.

Our data suggest that resveratrol reduces the migration of TG2-containing cells (SHY $_{\mathrm{TG} 2}$ and pancreatic cancer cells). In migratory cells, resveratrol increases $\mathrm{Ca}^{2+}$ levels and converts TG2 into open extended form (as detected by non-denaturing gel electrophoresis). The conversion of TG2 is sensitive to $\mathrm{Ca}^{2+}$ levels, and the open extended form is exclusively present in the plasma membrane fraction of migratory $\mathrm{SHY}_{\mathrm{TG} 2}$ and pancreatic cancer cells. Together, we show that $\mathrm{Ca}^{2+}$-mediated TG2 association to the cell membrane is responsible for the inhibitory effects of resveratrol on cell migration.

\section{Methods}

\section{Cell culture}

Human neuroblastoma SH-SY5Y cells (ATCC, Manassas, $\mathrm{VA}), \mathrm{SHY}_{\text {vector }} \mathrm{SHY}_{\mathrm{TG} 2}$, and $\mathrm{SHY}_{\text {mutant }}$ cells were maintained in Dulbecco's modified Eagle's medium (DMEM) with $10 \%$ fetal bovine serum (FBS; Atlanta Biologicals, Lawrenceville, GA). The pancreatic cancer cell lines Panc28 and Hs766T were maintained in RPMI medium with $10 \%$ FBS [12].

\section{Scratch assays for cell migration}

The cell mobility was determined by scratch assays [28]. Briefly, cells were grown in complete culture medium (with 10\% FBS) to a confluent monolayer (up to 90\%) in $100 \mathrm{~mm}^{2}$ tissue culture dishes, and treated with $10 \mu \mathrm{M}$ mitomycin c (Sigma-Aldrich, St. Louis, MO) for $30 \mathrm{~min}$ to inhibit cell proliferation. Cells were washed twice with complete medium and incubated with $1 \mu \mathrm{M}$ or $10 \mu \mathrm{M}$ of resveratrol (Sigma-Aldrich, St. Louis, MO). After $24 \mathrm{~h}$ incubation, a wound was made by scratching the dish uniformly with a pipette tip, washed twice with complete culture medium, and cells were further grown in complete culture medium in the presence of respective concentrations of resveratrol. Cells treated with a similar volume of dimethyl sulfoxide (DMSO) were used as control. Cell migration into the empty space was monitored by capturing images at different time points. The distance covered by cells in the empty area was calculated in $\%$.

\section{Collagen-transwell cell migration and matrigel-transwell cell invasion assays}

Cell migration studies were performed using transwell inserts with a filter of $8 \mu \mathrm{m}$ pore size (BD bioscience, San Jose, CA) and coated with $10 \mu \mathrm{g} / \mathrm{ml}$ collagen IV (Santa Cruz Biotechnology, Santa Cruz, CA). After 48 h treatment with resveratrol or DMSO, cells were trypsinized and $2 \times 10^{4}$ cells in serum-free medium with resveratrol were seeded into the upper chamber of the transwell insert. Culture medium with $10 \%$ FBS was added to the lower chamber. After $15 \mathrm{~h}$ incubation, cells migrated on the lower surface of inserts were stained with Hema3 stain (Fisher Scientific, Kalamazoo, MI), photographed, and counted from 10 randomly selected 
fields. Cell invasion studies were performed using matrigelcoated transwell plates (BD bioscience, San Jose, CA) following experimental procedure similar to collagentranswell migration assays.

\section{Immunofluorescence microscopy}

Scratch assays as described above were performed in Lab-TekII chamber slides (Fisher Scientific, Pittsburgh, PA). Cells were fixed with $4 \%$ paraformaldehyde in phosphate buffered saline (PBS), permeabilized with $0.2 \%$ Triton X-100/PBS, blocked with $5 \%$ bovine serum albumin (BSA) in PBS with $0.1 \%$ Tween-20 (PBST) at $4^{\circ} \mathrm{C}$ for overnight, and incubated with monoclonal anti-TG2 antibody (Neomarker/Thermoscientific, Rockford, IL) in $5 \% \mathrm{BSA} / \mathrm{PBST}$ at $4^{\circ} \mathrm{C}$ for overnight. Primary antibodies were detected with rhodamine-labeled anti-mouse IgG antibody ( $2 \mathrm{~h}$ incubation at room temperature). After washing with PBST, slides were mounted with Vectashield mounting media (Vector Laboratories, Burlingame, CA), and visualized under Nikon E-600 fluorescence microscope [29]. Nuclei were counterstained with DAPI (Sigma). TG2 on the outer surface of plasma membrane was detected as described by Akimov and Belkin [8]. Briefly, cells grown in chamber slides were incubated with anti-TG2 antibody $\left(10 \mu \mathrm{g} / \mathrm{ml}\right.$ in PBS) at $37^{\circ} \mathrm{C}$ for $4 \mathrm{~h}$, fixed with $4 \%$ paraformaldehyde/PBS for $20 \mathrm{~min}$, and blocked with 5\% BSA/PBS for $2 \mathrm{~h}$. Primary antibody (anti-TG2) was detected by rhodamine-conjugated goat anti-mouse IgG antibody under Nikon E-600 fluorescence microscope.

\section{Isolation of total cell proteins, plasma membrane proteins and Western blotting}

After treatments in scratch assays, cells near $(\sim 1 \mathrm{~mm}$ from the scratch) and away from the scratch were collected separately. For total cell extract preparation, cells were lysed with cell lysis buffer (Cell Signaling Technology, Danvers, MA), incubated for $30 \mathrm{~min}$ at $4^{\circ} \mathrm{C}$, centrifuged at $12,000 \mathrm{~g}$ for $10 \mathrm{~min}$ at $4^{\circ} \mathrm{C}$ and supernatant (containing total cell proteins) was collected. Cytoplasmic and plasma membrane protein enriched fractions were prepared using plasma membrane protein extraction kit (BioVision Inc, Milpitas, CA). Extracted proteins were stored at $-80^{\circ} \mathrm{C}$, and protein quantitation was performed by bicinconinic acid method (Pierce/ThermoScientific, Rockford, IL). Proteins were separated by SDSpolyacrylamide gel electrophoresis followed by Western blots as described previously [30]. The primary antibodies used were: TG2 (Neomarker/Thermoscientific), glyceraldehyde 3-phosphate dehydrogenase (GAPDH), $\mathrm{Na}^{+} / \mathrm{K}^{+}$ATPase (Santa Cruz Biotechnology, Santa Cruz, CA), and p-tyrosine (Millipore, Billerica, MA).

For total native protein isolation, cells were lysed in lysis buffer (0.1 M Tris, $\mathrm{pH}$ 7.4, 0.05\% Triton X-100, $0.5 \mathrm{mM}$ PMSF, $10 \mu \mathrm{g} / \mathrm{ml}$ leupeptin, $10 \mu \mathrm{g} / \mathrm{ml}$ pepstatin,
$1 \mathrm{mM} \mathrm{NaF}, 1 \mathrm{mM} \mathrm{Na} \mathrm{VO}_{4}, 1 \mathrm{mM} \beta$ - glycerophosphate, and $2.5 \mathrm{mM}$ sodium pyrophosphate) for $1 \mathrm{~h}$ on ice. After centrifugation at $12,000 \mathrm{~g}$ for $15 \mathrm{~min}$ at $4^{\circ} \mathrm{C}$, the supernatant (containing native proteins) was collected, and quickly stored at $-80^{\circ} \mathrm{C}$ until use. For non-denaturing gel electrophoresis, equal amount of proteins $(5 \mu \mathrm{g})$ were mixed with $5 \times$ loading buffer (without reducing agents and SDS), and separated in $12 \%$ native gel (without SDS) in running buffer (25 mM Tris, $192 \mathrm{mM}$ glycine) for $12 \mathrm{~h}$ at $4^{\circ} \mathrm{C}$. Separated proteins were transferred to PVDF membrane and Western blots were performed as described above.

\section{Transglutaminase activity and GTP-binding assays}

Extracted proteins $(5 \mu \mathrm{g})$ from total cells and cytoplasmic or membrane fractions were used to detect the transglutaminase activity of TG2 using tissue-transglutaminase colorimetric microassay kit (Covalab, Villeurbanne, France). The assay uses biotinylated T26 peptide (Biotin-pepT26) and spermine as substrates. In the presence of TG2, spermine is incorporated into the $\gamma$ carboxamide of the glutaminyl residue of the biotin-pepT26 to form a biotinpepT26- $\gamma$-glutamyl spermine. In brief, protein samples with assay mixture containing Biotin-pepT26 were incubated in spermine-coated 96-well microtiter plate, and the incorporation of spermine to Biotin-pepT26 was detected by sptreptavidin-avidine labelled peroxidase system. The color intensity as an indicator of TG2 activity was measured at $450 \mathrm{~nm}$ in a Spectramax spectrophotometer (Molecular Devices, Sunnyvale, CA). Photoaffinity labeling of GTP binding proteins with $\left[\alpha^{32} \mathrm{P}\right]-\mathrm{GTP}$ was performed as described previously [31]. Briefly, $5 \mu$ g protein samples (in $20 \mu \mathrm{l})$ in 96 well-plates were incubated with $20 \mu \mathrm{l}$ of reaction buffer (50 mM Hepes, pH 8.0, 1 mM EDTA, pH 8.0, $1 \mathrm{mM}$ DTT, $10 \%$ glycerol) containing $2 \mu \mathrm{Ci}$ of $\left[\alpha^{32} \mathrm{P}\right]-\mathrm{GTP}$ for $30 \mathrm{~min}$ at room temperature. Reactions were irradiated with UV-light $(254 \mathrm{~nm})$ for $15 \mathrm{~min}$ on ice. After irradiation, samples were mixed with $5 \times$ SDS loading buffer, boiled for $5 \mathrm{~min}$ and separated on SDS-polyacrylamide gels. Protein samples were transferred to PVDF membrane and the membranes were exposed to x-ray film. Similar membranes were used for Western blot and probed with anti-TG2 antibody.

\section{Detection of $\mathrm{Ca}^{2+}$ levels by fluorescence microscopy}

The level of $\mathrm{Ca}^{2+}$ in cells was determined by fluorescence microscopy using a membrane permeable $\mathrm{Ca}^{2+}$ indicator dye, Fluo4-AM (Molecular Probes, Grand Island, NY). Briefly, after treatment with resveratrol in scratch assays in Lab-TekII chamber slides, cells were incubated with Tyrode's solution (20 mM Hepes, pH 7.4, $130 \mathrm{mM} \mathrm{NaCl}$, $4.7 \mathrm{mM} \mathrm{KCl}, 1 \mathrm{mM} \mathrm{MgSO}$, $1.2 \mathrm{mM} \mathrm{KH}_{2} \mathrm{PO}_{4}, 5 \mathrm{mM}$ glucose) containing $10 \mu \mathrm{M}$ of Fluo4-AM dye and $0.1 \%$ pluronic F-127 (Molecular Probes) for $1 \mathrm{~h}$ at $37^{\circ} \mathrm{C}$ in a $5 \% \mathrm{CO}_{2}$ 
incubator. After washing twice with Tyrode's solution, cells were further incubated for $30 \mathrm{~min}$ at room temperature in the dark for de-esterification of dye. Slides were mounted in Vectashield mounting media (Vector Laboratories), and were visualized under fluorescence microscope. Fluorescence intensity in cells present near the scratch was quantified using Image-Pro Plus software and plotted.

\section{Data analyses}

Data are presented as the mean and standard deviation of at least 3 independent experiments. Comparisons were made among groups using one-way ANOVA followed by Tukey-Kramer ad hoc test (GraphPad software, La Jolla, CA). A $p$-value $<0.05$ was considered significant.

\section{Results}

TG2 enhances the migration and invasion of cancer cells which is inhibited by resveratrol

We first evaluated the role of TG2 in migration of $\mathrm{SH}$ SY5Y neuroblastoma cells by scratch assays and by collagen-transwell plate assays. Since the basal expression level of TG2 is very low in SH-SY5Y cells (nearly undetectable by Western blot, as shown in Figure 1A), we also used SH-SY5Y cells stably overexpressing TG2 protein $\left(\mathrm{SHY}_{\mathrm{TG} 2}\right)$ [32]. SH-SY5Y cells transfected with only the backbone plasmid $\left(\mathrm{SHY}_{\text {vector }}\right)$ were used as a control. Scratch assays in Figure 1A showed that $48 \mathrm{~h}$ after scratch, approximately $86 \%$ of the empty area of the original scratch was covered by $\mathrm{SHY}_{\mathrm{TG} 2}$ (Figure 1Aj) in comparison to $<50 \%$ migration by $\mathrm{SHY}_{\text {vector }}$ (Figure $1 \mathrm{Ad}$

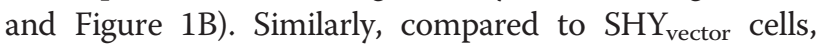
$\mathrm{SHY}_{\mathrm{TG} 2}$ cells exhibited more than a two-fold higher migration in collagen-transwell migration assays (Figure $1 \mathrm{Ca}$ and $\mathrm{d}$ and Figure 1D), and invasion through matrigelcoated transwell inserts (Figure 1Ea and $\mathrm{d}$ and Figure 1F). These results indicate that TG2 is one of the components required for cell mobility.

To detect whether the transglutaminase activity of TG2 is required for the migration, we performed scratch assays with SH-SY5Y cells stably expressing a full length TG2 mutant protein that lacks transamidation activity due to the mutation at amino acid position 277 (C277S, denoted as $\mathrm{SHY}_{\text {mutant }}$ ) [32]. Compared to $\mathrm{SHY}_{\mathrm{TG} 2}$ cell migration ( $~ 86 \%$ of migration, Figure $1 \mathrm{Aj})$, we observed only $53 \% \mathrm{SHY}_{\text {mutant }}$ cellular migration in scratch assays when grown in similar culture conditions (Figure 1Ap). Also, SHY mutant cells had a lower rate of migration and invasion pattern compared to $\mathrm{SHY}_{\mathrm{TG} 2}$ cells in collagentranswell (Figure $1 \mathrm{Cd}$ and g) and matrigel-transwell assays (Figure 1Ed and g), respectively.

The anticancer properties of resveratrol (res) have been well documented [25]. To test whether TG2 plays a role in the inhibitory effects of resveratrol on cancer cell migration and invasion, we performed migration and invasion assays in the presence of resveratrol. Exposure to resveratrol $(1 \mu \mathrm{M}$ or $10 \mu \mathrm{M})$ significantly inhibited the migration of $\mathrm{SHY}_{\mathrm{TG} 2}$ cells in scratch assays (Figure $1 \mathrm{Aj}, \mathrm{k}$ and $\mathrm{l}$ and $\mathrm{B}$ ) and in collagen-transwell assays (Figure $1 \mathrm{Cd}$, e, $\mathrm{f}$, and D) as well as the invasion through the matrigelbarrier in transwell inserts (Figure 1Ed, e, $f$ and bar in F). In contrast, resveratrol did not affect $\mathrm{SHY}_{\text {vector }}$ and $\mathrm{SHY}_{\text {mutant }}$ cell migration (in scratch assays or through collagentranswell plates, Figure 1A-D) or invasion (through matrigel-transwell inserts, Figure $1 \mathrm{E}$ and F).

We further verified the resveratrol-inhibited migration and invasion pattern in TG2 expressing human pancreatic cancer cell lines Panc-28 and Hs766T [12]. After $48 \mathrm{~h}$ of DMSO treatment in scratch assays, Panc28 and Hs766T cells migrated into the empty area by almost $89 \%$ and $85 \%$, respectively. The addition of $1 \mu \mathrm{M}$ or $10 \mu \mathrm{M}$ resveratrol significantly reduced the mobility of all these cell lines in a dose dependent manner (Figure 1G). Resveratrol (1 or $10 \mu \mathrm{M}$ ) also significantly reduced the migration and invasion of Panc-28 cells in transwellmigration and transwell-invasion assays, respectively (Figure 1H).

\section{Resveratrol increases the immunoreactivity of TG2 in migratory $\mathrm{SHY}_{\mathrm{TG} 2}$ and pancreatic cancer cells}

To determine whether resveratrol inhibits the migration of $\mathrm{SHY}_{\mathrm{TG} 2}$ and pancreatic cancer cells by altering the expression and/or cellular distribution of TG2, we first performed immuno-fluorescence studies for TG2 in scratch assays. The immunofluorescence images in Figure $2 \mathrm{~A}$ demonstrated that the immunoreactivity for TG2 remains equally distributed after $48 \mathrm{~h}$ DMSO-treated $\mathrm{SHY}_{\mathrm{TG} 2}$ cells (Figure 2Ac). In contrast, following $48 \mathrm{~h}$ resveratrol treatment $(1 \mu \mathrm{M}$ or $10 \mu \mathrm{M})$ a significant increase in the fluorescent signal for TG2 (red in color and indicated by arrow) was observed in the $\mathrm{SHY}_{\mathrm{TG} 2}$ cells present only near the scratch (Figure 2Ai and $\mathrm{o}$ and B). In the case of the SHY mutant cells, the TG2 immunoreactivity remains unchanged in DMSO and resveratrol $1 \mu \mathrm{M}$ or $10 \mu \mathrm{M}$ treated cells (Figure 2Ae, $\mathrm{k}$ and $\mathrm{q}$ and B). TG2 immunoreactivity was not detected in either untreated or resveratrol treated $\mathrm{SHY}_{\text {vector }}$ cells (Figure 2Aa, g and $\mathrm{m}$ and B). Similarly, $48 \mathrm{~h}$ incubation with $1 \mu \mathrm{M}$ or $10 \mu \mathrm{M}$ concentration of resveratrol increased TG2 immunoreactivity in Panc-28 (Figure 2Ca-f, and D) and Hs766T cells (Figure 2Cg-l, and D) present near the scratch (as shown by arrow).

\section{TG2, in response to resveratrol, is not localized to} extracellular side of plasma membrane or secreted into the medium

To test whether externalization of cytosolic TG2 was involved in the anti-invasive effects of resveratrol, we performed an immunofluorescence assay (to examine 

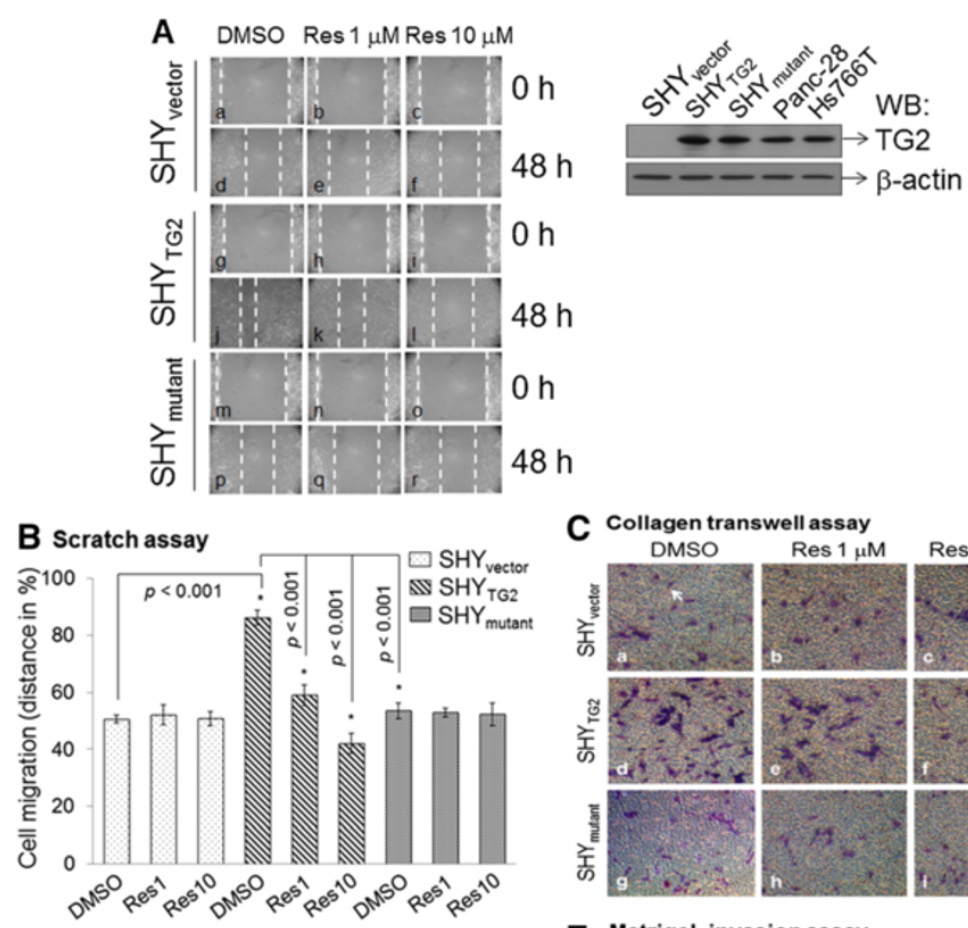

C Collagen transwell assay
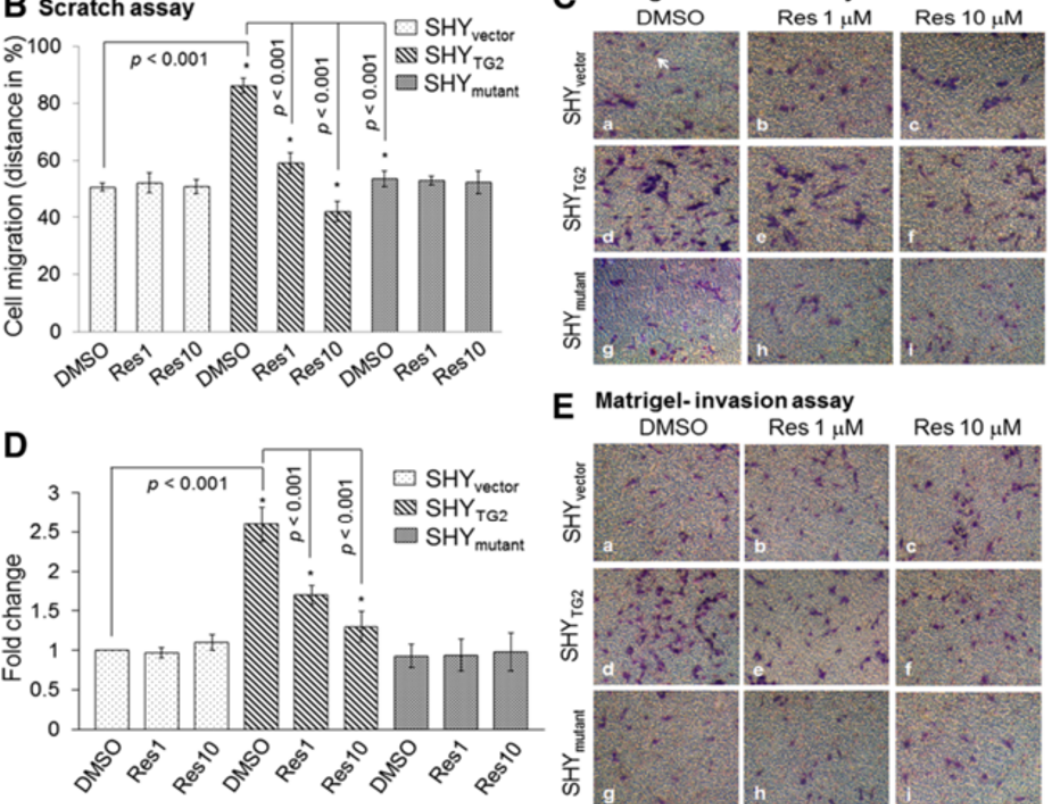

E Matrigel-invasion assay

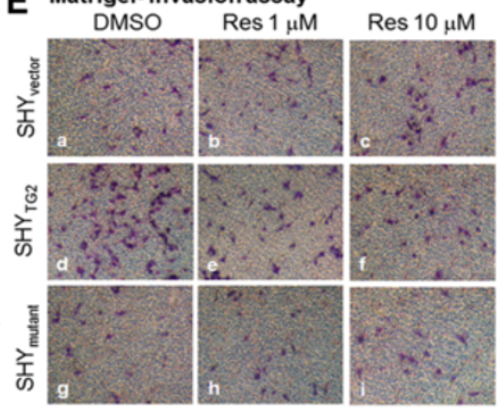

$\mathbf{F}$

G Scratch assay
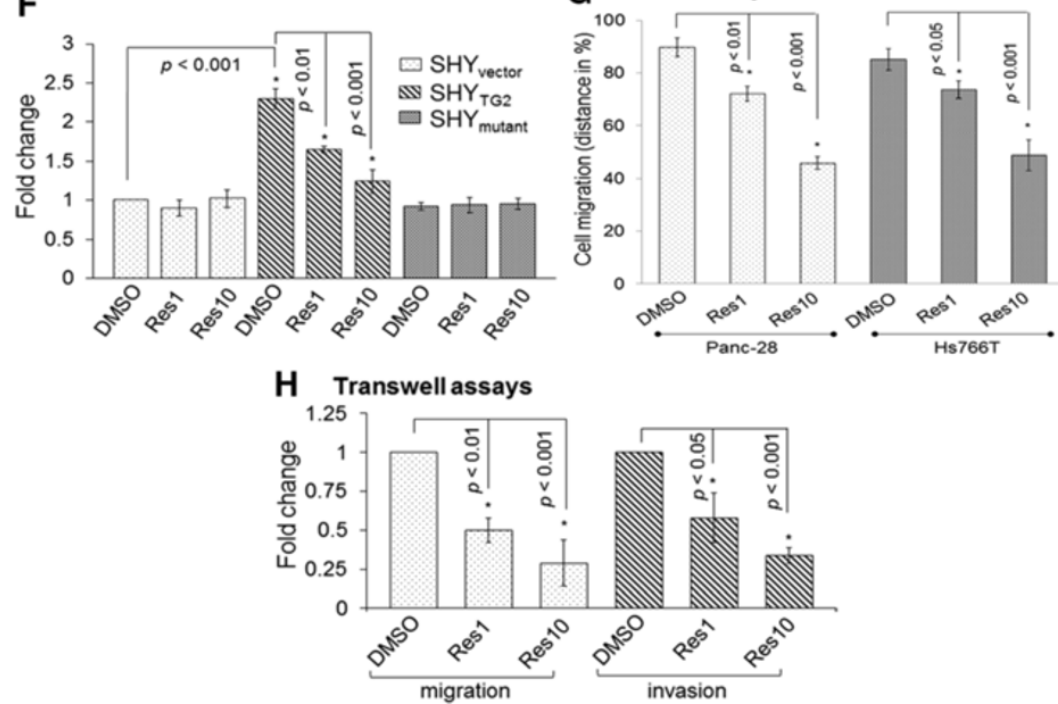

Figure 1 (See legend on next page.) 
(See figure on previous page.)

Figure 1 Cell migration and invasion assays. (A) Representative images from the scratch assays showing the migration of SHY vector, $S H Y_{T G 2}$, and SHY mutant cells. Mytomycin C treated cells were preincubated with resveratrol $(1 \mu \mathrm{M}$ and $10 \mu \mathrm{M})$ for $24 \mathrm{~h}$; a scratch was made and further incubated with resveratrol. At $0 \mathrm{~h}$ and $48 \mathrm{~h}$ after scratch, cells were photographed. Dotted lines represent the edge of migrated cells in the scratch. Upper right panel: Western blot for TG2 protein using $10 \mu \mathrm{g}$ total cell extract from $\mathrm{SHY}_{\text {vector, }} \mathrm{SHY}_{\mathrm{TG}}, \mathrm{SHY}$ mutant, Panc-28, and Hs766T cells. (B) The distance covered by cells in the original empty area was measured and plotted in \%. Bars represent mean \pm SD of three independent experiments. ${ }^{*} p$ value $<0.05$. (C-E) Images from collagen-transwell and matrigel-transwell assays. After $48 \mathrm{~h}$ with or without resveratrol treatment, cells were trypsinized and seeded on collagentranswell (C) or matrigel-transwell inserts in the presence of resveratrol (E). After $15 \mathrm{~h}$, migrated cells on the lower side of inserts were stained with Hema-3 stain (arrow), counted from ten random fields and plotted (D and F). Bars are mean \pm SD of at least three independent experiments and ${ }^{*} p$ value $<0.05$. (G) Bar diagram represents the migration of Panc-28 and Hs766T cells in scratch assays in the presence of resveratrol as performed with SH-SY5Y cells. Migrated cells into the original empty area were photographed and plotted. Bars are mean \pm SD of three independent experiments. * $p$ value $<0.05$. (H) Migration and invasion assays for Panc-28 cells were carried out as with neuroblastoma cells in transwell inserts. Migrated/invaded cells were counted from 10 random fields and plotted. Bars are mean \pm SD of three independent experiments. ${ }^{*} p$ value $<0.05$.

TG2 on outer surface of plasma membrane) and ELISA (to detect TG2 levels in culture medium). After $48 \mathrm{~h}$ treatment with or without resveratrol in scratch assays, nonpermeabilized cells were incubated with anti-TG2 antibody. Our immunofluorescence results in Figure 3A and B demonstrate that resveratrol did not alter the immunoreactivity of TG2 on the external surface of $\mathrm{SHY}_{\mathrm{TG} 2}$ cells (Figure 3Ac, i and o), as well as on Panc-28 (Figure 3Ba-f) and Hs766T cells (Figure 3Bg-1). Similarly, our ELISA result shows that resveratrol did not significantly alter TG2 secretion in culture medium collected from resveratroltreated and untreated $\mathrm{SHY}_{\mathrm{TG} 2}$ and Panc-28 cells in scratch assays (Additional file 1: Figure S1).

Resveratrol increases the translocation of TG2 to the plasma membranes of $\mathrm{SHY}_{\mathrm{TG} 2}$ and Panc-28 cells present near the scratch

To test whether the cellular distribution and/or enzymatic activity of TG2 is altered by resveratrol as it inhibits the migration of $\mathrm{SHY}_{\mathrm{TG} 2}$ and Panc-28 cells, we subsequently

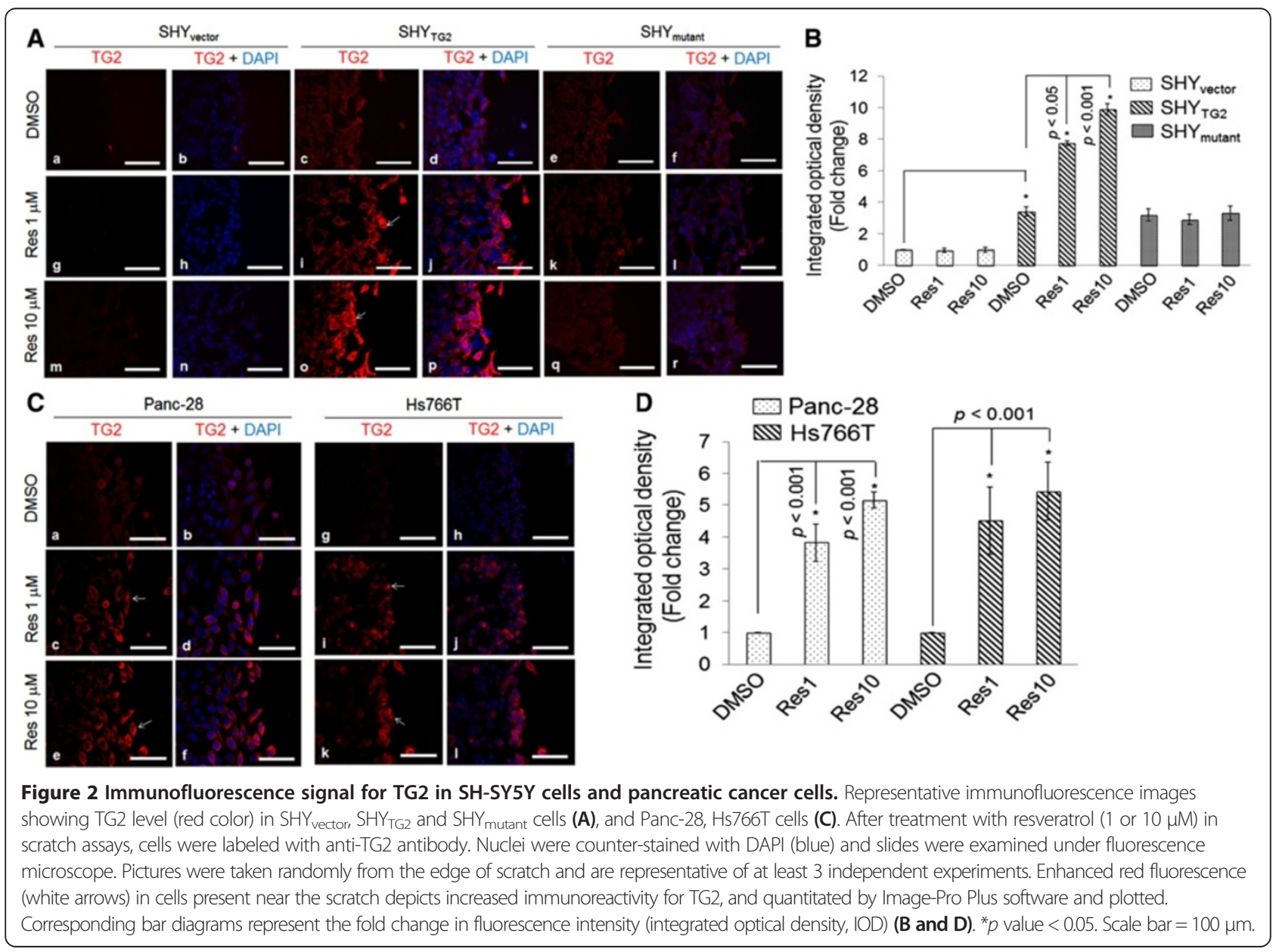


determined TG2 protein level and enzymatic activity (GTP-binding as well as transamidation) in these cells. After $48 \mathrm{~h}$ in scratch assays, cells near the scratch $(\sim 1 \mathrm{~mm}$ from the scratch) and away from the scratch were collected separately, total cell extracts were prepared and Western blots with anti-TG2 antibody was performed. Western blots for TG2 in Figure 4A depicted that TG2 protein level is almost similar in total cell extracts prepared from resveratrol-treated or -untreated $\mathrm{SHY}_{\mathrm{TG} 2}$ and Panc-28 cells present near and away from the scratch. However, Western blots in Figure 4B and C (upper panel) demonstrated that TG2 protein band was detected in the membrane fraction of cells present near the scratch only in resveratrol treated $\mathrm{SHY}_{\mathrm{TG} 2}$ and Panc-28 cells, but not in DMSO-treated cells (Figure 4B and C, lanes 4-6). Such a TG2 band was not observed in the membrane fractions from DMSO- or resveratrol-treated cells present away from the scratch (Figure 4B and C, upper panel, lanes 1012). The cytosolic fractions isolated from close to or away from the scratch had almost similar levels of TG2 proteins in DMSO- and resveratrol-exposed cells (Figure 4B and C, upper panel, lanes 1-3 and 7-9). The fractions that contain TG2 protein exhibit comparable levels of GTPbinding activity (Figure 4B and C, lower panel, lanes 1-3, 5,6 and $7-9$ ).

The bar diagram in Figure 4D depicted that resveratrol exposure $(1 \mu \mathrm{M}$ or $10 \mu \mathrm{M})$ significantly increased the transamidation activity (as determined by tissue transglutaminase colorimetric microassay kit, Covalab) in $\mathrm{SHY}_{\mathrm{TG} 2}$ total cell extracts prepared from the cells present near the scratch (for res $1 \mu \mathrm{M}, p<0.005$; and for res $10 \mu \mathrm{M}, p<0.001$ vs. DMSO). Such changes in transamidation activity by resveratrol were not observed in $\mathrm{SHY}_{\mathrm{TG} 2}$ total cell extracts prepared from the cells present away from the scratch (Figure 4D). Resveratrol exposure significantly increased transamidation activity of TG2 in cytoplasmic and membrane fractions prepared from $\mathrm{SHY}_{\mathrm{TG} 2}$ and Panc-28 cells present near the scratch, but not in cells present away from the scratch (Figure 4E and F).
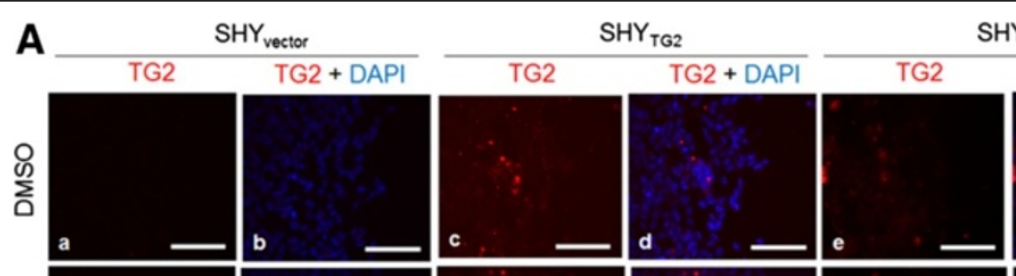

$\mathrm{SHY}_{\text {mutant }}$
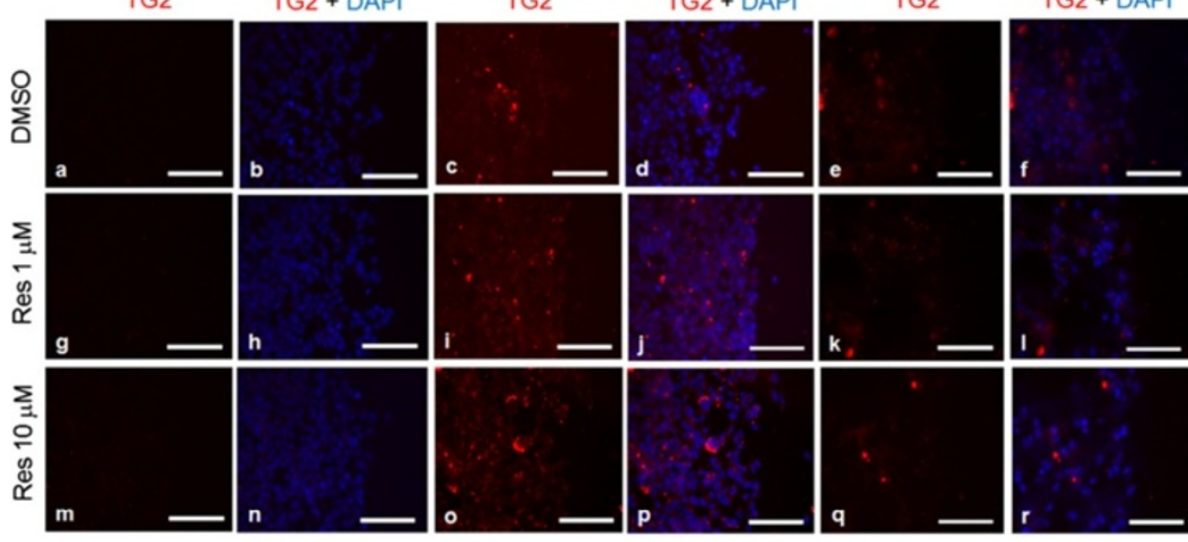

B

Panc-28

Hs766T

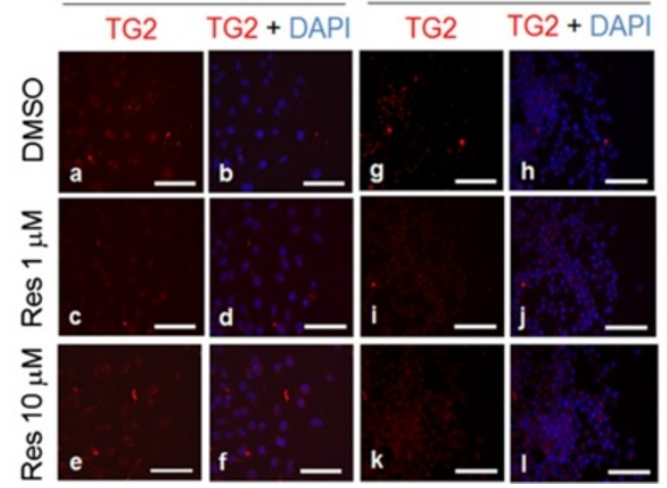

Figure 3 Determination of extracellular levels of TG2 in response to resveratrol. Representative immunofluorescence images showing extracellular TG2 level (red) in $\mathrm{SHY}_{\text {vector, }} \mathrm{SHY}_{\mathrm{TG} 2}$, and $\mathrm{SHY}$ mutant (A), and Panc-28 and Hs766T cells (B). After $48 \mathrm{~h}$ with or without resveratrol (1 or $10 \mu \mathrm{M}$ ) treatment in scratch assays, extracellular TG2 was detected using anti-TG2 antibody. Nuclei were stained with DAPI and visualized under fluorescence microscopy. Pictures are representative of at least 3 independent experiments. Scale bar $=100 \mu \mathrm{m}$. 


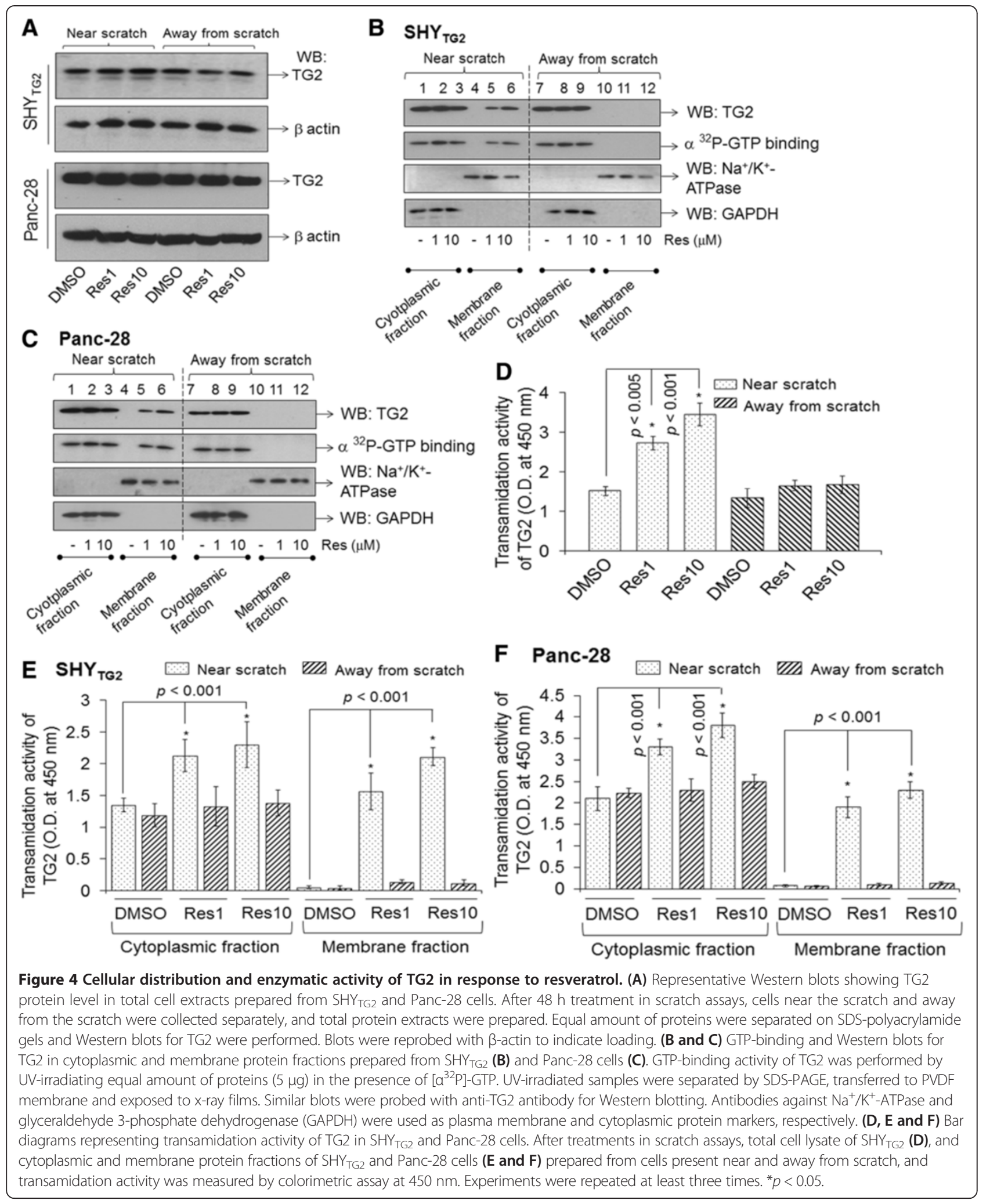


Resveratrol induces conversion of compact TG2 into its open slow mobility form in cells present near the scratch Next, we sought to determine how resveratrol increases $\mathrm{TG} 2$ immunoreactivity only in $\mathrm{SHY}_{\mathrm{TG} 2}$ and pancreatic cancer cells present near the scratch. We subsequently performed Western blots with anti-TG2 antibody under nondenaturing conditions. The representative Western blots in Figure 5A depict that in addition to the major TG2 protein band $(\sim 87 \mathrm{kDa})$ another protein band of slower mobility ( $95 \mathrm{kDa})$ was detected by anti-TG2 antibody in native protein samples from resveratrol-treated $\mathrm{SHY}_{\mathrm{TG} 2}$ and Panc-28 cells present near the scratch (Figure 5A, upper and middle panel, lanes 2 and 3), but not in DMSO-treated cells (Figure 5A, lane 1). However, the slower mobility form of TG2 was not detected in DMSO- or resveratroltreated $\mathrm{SHY}_{\mathrm{TG} 2}$ and Panc-28 cells present away from the scratch (Figure 5A, lanes 4-6). Despite the appearance of slower mobility TG2 form, we did not detect any change in the level of higher mobility TG2 form. In SHY mutant cells only one TG2 band of higher mobility ( $\sim 87 \mathrm{kDa})$ was detected in control and treatment groups (Figure 5A, lower panel, lanes 1-6).

Since resveratrol induces translocation of TG2 to the plasma membranes (Figure 4B and C); we further evaluated the forms of TG2 in membrane fractions. The representative Western blots for TG2 in non-denaturing conditions demonstrated that TG2 protein band with slower migration was only detected in the membrane fractions prepared from resveratrol-treated $\mathrm{SHY}_{\mathrm{TG} 2}$ and Panc-28 cells present near the scratch (Figure 5B, upper two panels, lanes 4-6). A TG2 band of similar mobility was also present in the cytoplasmic fractions prepared from resveratrol-treated cells present near the scratch (Figure 5B, lanes 2 and 3). However, the TG2 protein band with higher mobility was not present in resveratrol-treated membrane protein fractions, but present in the cytoplasmic fraction from DMSO- and resveratrol-treated samples (Figure 5B, lanes 1-6). These data indicated that a resveratrol-induced slower mobility form of TG2 exists in migratory $\mathrm{SHY}_{\mathrm{TG} 2}$ and Panc-28 cells, and this is the exclusive TG2 form present in the plasma membrane of migratory cells.

Further we checked post-translational modification, phosphorylation, of TG2 [33] in native total cellular proteins from $\mathrm{SHY}_{\mathrm{TG} 2}$ and Panc-28 cells present near and away from the scratch, followed by Western blots under non-denaturing conditions using anti-tyrosine antibody. Blots in Figure 5C depict that the anti-tyrosine antibody detects only a single protein band in both resveratrol-

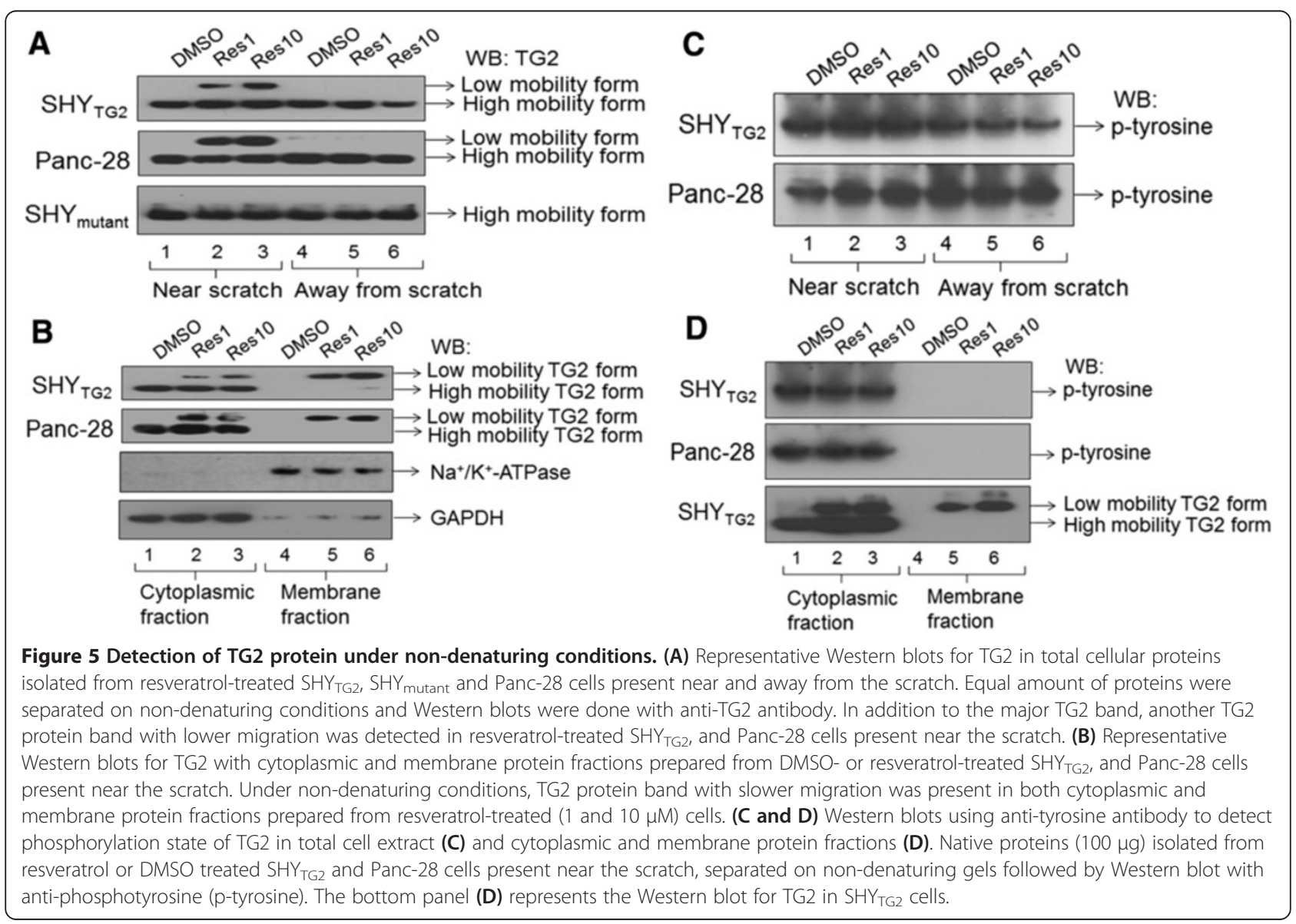


treated and untreated native protein samples that corresponds to the TG2 protein of the higher mobility form (lanes 2 and 3). Also, irrespective of resveratrol treatment, anti-tyrosine antibody detects only a single band in native proteins from cytoplasmic fractions, but not in plasma membrane fractions from $\mathrm{SHY}_{\mathrm{TG} 2}$ and Panc-28 cells present near the scratch (Figure 5D, upper two panels). However, we did not observe serine phosphorylation in these conditions (data not shown). This indicates that the higher mobility form of TG2 is the phosphorylated form, and the slower mobility form of TG2, which appears in the presence of resveratrol, is a non-phosphorylated form. This also suggests that resveratrol-induced dephosphorylation of the higher mobility form of TG2 may be involved in the conversion of the compact higher mobility form into slower mobility open structure TG2 form.

\section{Resveratrol increases intracellular $\mathrm{Ca}^{2+}$ levels in cells present near the scratch}

Since intracellular $\mathrm{Ca}^{2+}$ levels determine TG2 conformational state [34], we hypothesize that the slower migratory form of TG2 may result from resveratrol-induced changes in intracellular calcium concentrations [35]. To test this possibility, we first performed immunofluorescence studies using a membrane permeable $\mathrm{Ca}^{2+}$ indicator dye, Fluo4-AM, in scratch assays. The fluorescence intensity in cells near the scratch was quantified as integrated optical density (IOD) by Image-Pro Plus software and plotted (Figure 6A and $\mathrm{B}$ ). We found that resveratrol $(1 \mu \mathrm{M}$ or $10 \mu \mathrm{M}$ for $48 \mathrm{~h})$ significantly increased $\mathrm{Ca}^{2+}$ fluorescence intensities in $\mathrm{SHY}_{\mathrm{TG} 2}$ cells present near the scratch (Figure 6Af, g and h). In our experiments, we observed that along with migrating cells, some cells away from the scratch also exhibited

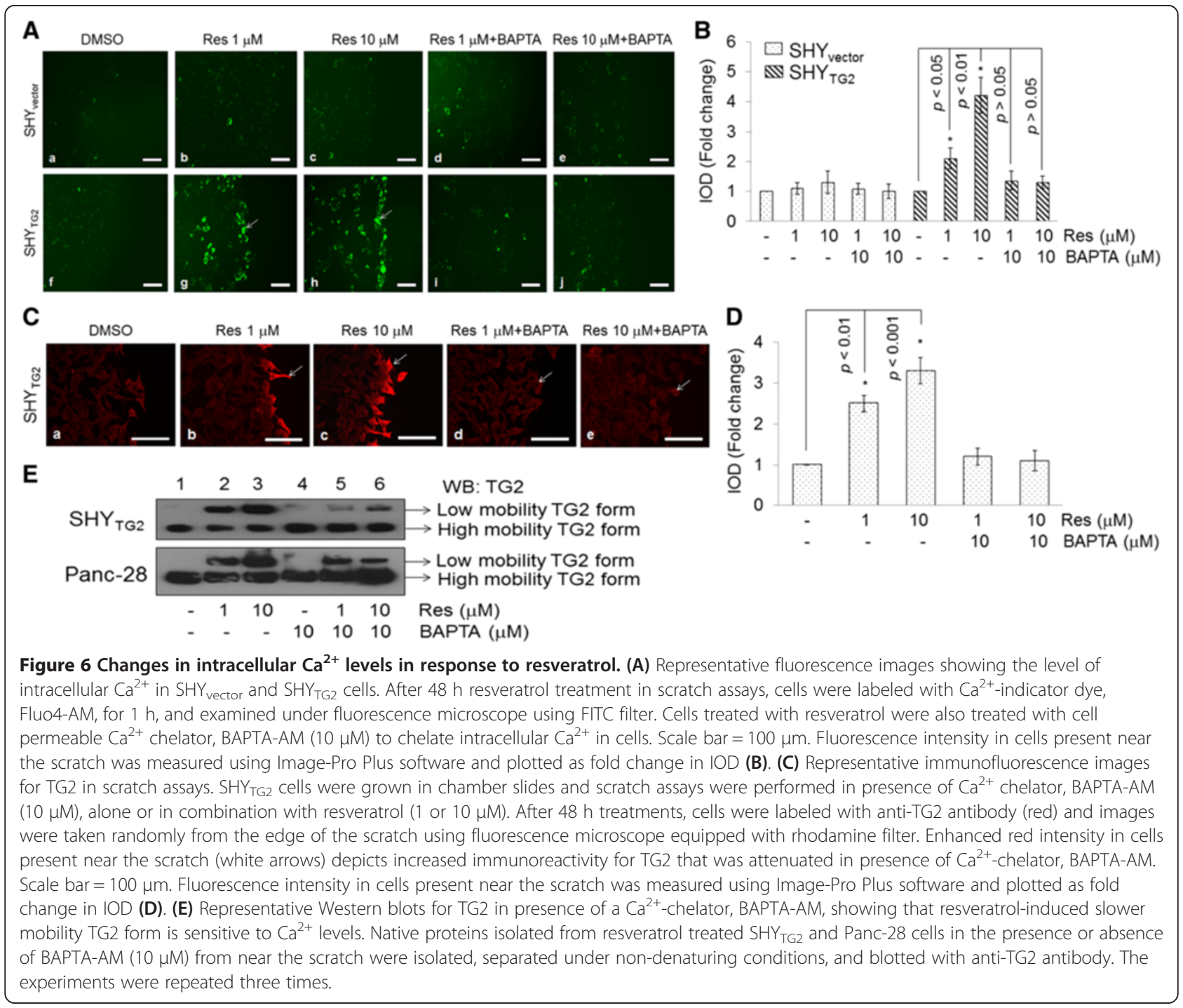


increased calcium fluorescence. However, the response was more significant in the cells near the scratch. Changes in the cytoplasmic calcium levels are known to be transient and all the cells do not fluoresce at the same time. Therefore we did not get synchronized calcium labeling. The effect on the cells away from the scratch may be due to the secondary response of the cells near to scratch, also shown in some previous studies [36,37]. Similar increase in fluorescence intensity of $\mathrm{Ca}^{2+}$ was not observed when $\mathrm{SHY}_{\mathrm{TG} 2}$ cells were incubated with a $\mathrm{Ca}^{2+}$-chelator, BAPTA-AM $(10 \mu \mathrm{M})$, in the presence of either concentration of resveratrol $(1$ or $10 \mu \mathrm{M})$ (Figure 6Ai and j). In contrast to $\mathrm{SHY}_{\mathrm{TG} 2}$ cells, we did not observe such resveratrol-induced increased $\mathrm{Ca}^{2+}$ fluorescence in $\mathrm{SHY}_{\text {vector }}$ cells (Figure 6Aa-e).

The increased levels of $\mathrm{Ca}^{2+}$ in resveratrol-treated migratory $\mathrm{SHY}_{\mathrm{TG} 2}$ cells prompted us to test whether changes in intracellular $\mathrm{Ca}^{2+}$ level are responsible for the increased TG2 immunoreactivity in resveratrol-treated $\mathrm{SHY}_{\mathrm{TG} 2}$ cells (as seen in Figure 2Ai and o). We further checked the immunofluorescence signal for TG2 in the presence of a $\mathrm{Ca}^{2+}$-chelator, BAPTA-AM $(10 \mu \mathrm{M})$, in combination with resveratrol (1 or $10 \mu \mathrm{M}, 48 \mathrm{~h}$ ) in scratch assays. Our immunofluorescence data demonstrated that BAPTA-AM significantly attenuated the resveratrol-induced immunoreactivity of TG2 (red color, shown by arrow) and was similar to control-level in migratory cells (Figure $6 \mathrm{C}$ and $\mathrm{D}$ ). To further confirm the $\mathrm{Ca}^{2+}$-induced changes in TG2 protein, we performed Western blots for TG2 under non-denaturing conditions with native proteins isolated from BAPTA-AM $(10 \mu \mathrm{M})$ and resveratrol (1 or $10 \mu \mathrm{M}, 48 \mathrm{~h}$ ) treated $\mathrm{SHY}_{\mathrm{TG} 2}$ cells present near the scratch. The Western blot for TG2 in Figure 6E demonstrated that presence of BAPTA-AM reduces the intensity of the slower mobility form of TG2 in resveratrol-treated cells (compare lane 2, 3 and 5, 6). These results indicated the slower migratory form of TG2 which appears in the presence of resveratrol is sensitive to $\mathrm{Ca}^{2+}$ ions, and this form of TG2 may be responsible for the higher immunoreactivity of TG2 in cells present near the scratch.

\section{Discussion}

The role of TG2 in cancer cell metastasis and drug resistance is well documented [11], however, its precise molecular mechanism in migration and invasion is not fully understood. Here we report that TG2 promotes migration and invasion of SH-SY5Y neuroblastoma cells. In contrast, we have previously shown that retinoic acid-induced TG2 promotes differentiation of SH-SY5Y cells [21]. In order to understand the opposite behavior of TG2 on cell migration and differentiation, we used a natural compound, resveratrol. Various in vivo studies in cancer models including neuroblastoma confirms the anticancer properties of resveratrol $[24,25]$, however, in vitro studies have needed higher concentrations ( $>100 \mu \mathrm{M})$ of resveratrol to induce apoptosis in cancer cells. Moreover, such concentrations are not achievable in vivo. Hence we use physiologically relevant concentrations of resveratrol $(1 \mu \mathrm{M}$ and $10 \mu \mathrm{M})$ in our studies to assess its effects in cancer cells. Our experiments showed that resveratrol even at $1 \mu \mathrm{M}$ concentration significantly inhibited migration/invasion of TG2 containing cells ( $\mathrm{SHY}_{\mathrm{TG} 2}$ and pancreatic cancer cells) (Figure 1A-H). The observed inhibitory effects of resveratrol on migration was not due to the lower viability of cells, since the number of viable cells following DMSO and resveratrol treatment $(1 \mu \mathrm{M}$ or $10 \mu \mathrm{M})$ were almost similar in cell viability assays carried out by trypan-blue exclusion method (Additional file 1: Figure S2). We also observed that resveratrol significantly increased the TG2 immunoreactivity in migratory $\mathrm{SHY}_{\mathrm{TG} 2}$ and pancreatic cancer cells (Figure 2) without affecting TG2 protein level (Figure 4A). These results prompted us to investigate how resveratrol increases TG2 immunoreactivity without changing the protein levels in cells. The Western blots under non-denaturing conditions detects an additional TG2 protein band of slower mobility in total native proteins from resveratrol-treated $\mathrm{SHY}_{\mathrm{TG} 2}$ and Panc-28 cells present near the scratch (Figure 5A, lanes 2 and 3). Although both cellular fractions (cytoplasmic and plasma membrane) exhibit the slower mobility TG2 band, the membrane fractions exclusively has this TG2 form in resveratroltreated $\mathrm{SHY}_{\mathrm{TG} 2}$ and Panc- 28 cells present near the scratch (Figure 5B, lanes 2, 3, 5 and 6). The slow mobility band may be the open structure form of TG2 and the higher mobility band may be compact form of TG2, also visualized by others using native polyacrylamide gel electrophoresis $[5,34,38]$.

Furthermore, we also observed a significant increase in fluorescence levels of $\mathrm{Ca}^{2+}$ in response to resveratrol in migratory $\mathrm{SHY}_{\mathrm{TG} 2}$ cells (Figure 6Ag and $\mathrm{h}$ ). The reduced immunoreactivity of TG2 by depleting the intracellular $\mathrm{Ca}^{2+}$ with BAPTA-AM in resveratrol-treated $\mathrm{SHY}_{\mathrm{TG} 2}$ migrating cells (Figure 6Cb-e) correlate with the $\mathrm{Ca}^{2+}$ dependent changes in TG2 immunoreactivity. The observation that BAPTA-AM reduced the level of the slower mobility form of TG2 in resveratrol treated cells (Figure 6E, lanes 5 and 6) further support the requirement of $\mathrm{Ca}^{2+}$ ions in the structural modification of TG2. Resveratrol induced calcium release is supported by recent studies in myotubes and chromaffin cells $[35,37]$. Previous reports suggest the existence of two forms of TG2 depending on the $\mathrm{Ca}^{2+}$ ion concentrations in cells with a compact closed form at low $\mathrm{Ca}^{2+}$ concentration and an open extended form at higher $\mathrm{Ca}^{2+}$ concentration [34,39-44]. Hence the observed resveratrolinduced increased $\mathrm{Ca}^{2+}$ levels (Figure 6) sensitize TG2 which in turn converts from the compact form into the open extended structure (slow mobility form) in the cytoplasm, and this extended slow mobility form mobilizes to the plasma membrane. These observations suggest that the increased 
immunoreactivity of TG2 in resveratrol-treated migratory $\mathrm{SHY}_{\mathrm{TG} 2}$ and pancreatic cancer cells is due to greater antigen accessibility of the anti-TG2 antibody to the $\mathrm{Ca}^{2+}$-sensitized open low migratory form of TG2. This also explains the reduced levels of TG2 immunoreactivity in $\mathrm{SHY}_{\text {mutant }}$ cells (Figure 2) even in presence of similar levels of total TG2 protein as in $\mathrm{SHY}_{\mathrm{TG} 2}$ cells. Resveratrol-induced increased $\mathrm{Ca}^{2+}$ levels might fail to convert mutated TG2 into the open form, reducing antigen access of the anti-TG2 antibody in SHY mutant cells.

Absence of the slow molecular form of TG2 after incubation of native total $\mathrm{SHY}_{\mathrm{TG} 2}$ proteins with resveratrol (1 or $10 \mu \mathrm{M}$ ) alone or in combination with $\mathrm{Ca}^{2+}$ in an in vitro cell-free system (Additional file 1: Figure S3) suggest that the conversion of closed to open structure form of TG2 is not due to a direct interaction between resveratrol and TG2, and that other factors might also be involved in resveratrol-induced TG2 conversion. We also tested the possible interaction between TG2 and resveratrol by computational modeling using different approaches. The $\mathrm{COACH}$ server and TM-ALIGN analysis failed to predict the significant interaction, however, another program BSPSLIM (for low-resolution ligand-protein docking) showed some docking positions on TG2, but it was difficult to evaluate if they indeed interact (Additional file 1: Figure S4a and S4b). Thus the cell-free system and bioinformatics approaches concluded that resveratrol did not interact significantly with TG2. Our observation that the slower mobility TG2 form is non-phosphorylated and the higher mobility form is phosphorylated (Figure 5C) suggests that resveratrol induces dephosphorylation of the slower mobility TG2 form which travels from cytoplasm to plasma membrane. How shuttling of the $\mathrm{Ca}^{2+}$-sensitive open slow mobility dephosphorylated TG2 form to cytoplasmic side of plasma membrane occurs is not clear. A recent study revealed that a heat shock protein (Hsp70) mediates TG2 transport to the plasma membrane [45]. Our results that the open structure slow mobility TG2 band was present in both cytoplasmic and membrane fractions, and the higher mobility form was present only in cytoplasmic fractions (not in membrane fractions) in $\mathrm{SHY}_{\mathrm{TG} 2}$ and Panc-28 cells (Figure 5B) suggests that a chaperone-like activity of Hsp70 might help in $\mathrm{Ca}^{2+}$ - induced TG2 conversion, and interaction of Hsp-70 to the open slow mobility TG2 form might facilitate the transport of this form of TG2 from cytoplasm to plasma membrane. Previous studies indicate that acetylation [46] and ubiquitination of TG2 [47] inhibit its transamidation activity and degrade the protein into smaller fragments. In our studies increased transamidation activity by resveratrol and absence of smaller proteolytic fragments of TG2 suggest that resveratrol does not induce the acetylation and ubiquitination of TG2.

In response to various stimuli, TG2 is either transported to the cytoplasmic or extra-cellular side of plasma membrane [48]. On the cytoplasmic side of the plasma membrane, TG2 activates phospholipase C (PLC) and RhoA-ROCK-2 signaling pathways $[21,22,31]$, while on the cell surface, TG2 acts as a co-receptor for integrins to promote cell attachments [49]. TG2 is known to positively regulate the expression and activity of metalloproteinases (MMPs)-2 and -9 in cancer cells [10,50]. MMPs are a family of secreted proteins known to promote cancer cell migration through acting in extracellular environment [51]. In our scratch assays with $\mathrm{SHY}_{\mathrm{TG} 2}$ and Panc- 28 cells, resveratrol at $1 \mu \mathrm{M}$ or $10 \mu \mathrm{M}$ concentrations did not affect TG2 localization to the extracellular membrane surface (Figure $3 \mathrm{~A}$ and $\mathrm{B}$ ) or its secretion into culture medium (ELISA, Additional file 1: Figure S1). Also we did not observe any effects on enzymatic activity of matrix metalloproteinases (MMPs)-2 and -9 in culture medium collected after resveratrol $(1$ or $10 \mu \mathrm{M})$ treatments in scratch assays (as revealed by gelatin zymography, Additional file 1: Figure S5) suggesting that intracellular (not extracellular) TG2-mediated signaling events are involved in the inhibitory effects of resveratrol in cell migration. Incubation with Sirtinol (an inhibitor of Sirt-1, a well-known substrate of resveratrol) did not attenuate the resveratrol-effects on migration of $\mathrm{SHY}_{\mathrm{TG} 2}$ and Panc-28 cells suggesting that the observed inhibition in cell migration by resveratrol is Sirt1-independent (Additional file 1: Figure S6) [52].

By demonstrating that resveratrol induces TG2 translocation to the plasma membrane, and increases intracellular $\mathrm{Ca}^{2+}$ levels, we propose a putative model which explains the underlying mechanism of resveratrol effects on TG2mediated cell migration (Figure 7). Under normal conditions, cytoplasmic TG2 remains in its phosphorylated compact form and induces cell migration and invasion. Its GTPbinding function plays a major role in mediating these

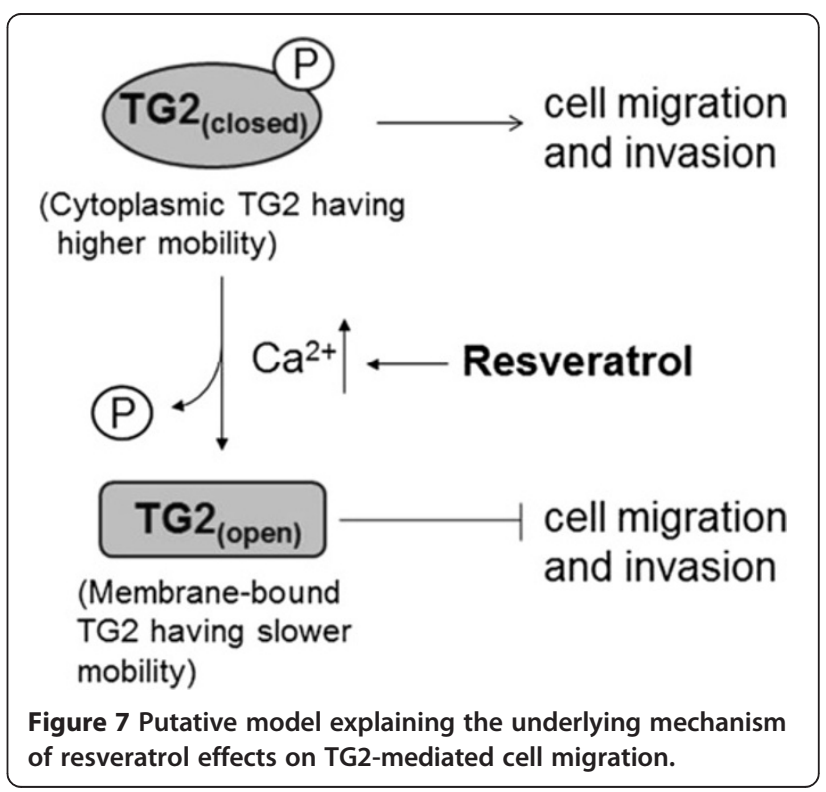


effects and requires low intracellular calcium concentrations. Following resveratrol exposure increased intracellular $\mathrm{Ca}^{2+}$ levels converts closed TG2 form into the open extended form which in turn, probably with the help of Hsp70 protein, translocates to the cytoplasmic side of plasma membranes. On the plasma membrane, TG2 activates the PLC signaling pathway [31]. Activation of PLC $\delta$ pathways further amplify the $\mathrm{Ca}^{2+}$ levels in the cytoplasm by releasing $\mathrm{Ca}^{2+}$ from intracellular organelles, which in turn increases the transamidation activity of TG2 for the prevention of cell migration/invasion. The observations that transamidation activity of TG2 is required for cell migration is supported by less mobility of transamidation-defective SH-SY5Y cells $\left(\mathrm{SHY}_{\text {mutant }}\right)$ in scratch assays (Figure $\left.1 \mathrm{~A}\right)$, and the reduced migration of $\mathrm{SHY}_{\mathrm{TG} 2}$ cells and Panc-28 cells in the presence of a TG2 transamidation inhibitor, monodensylcadevarine (Additional file 1: Figure S7). A recent report demonstrating the role of a $\mathrm{Ca}^{2+}$-binding protein, S100A4, in TG2-mediated migration further supports our observations of a $\mathrm{Ca}^{2+}$ requirement for TG2-mediated cancer cell migration [53].

\section{Conclusions}

Together, the present study indicates that TG2 is one of the proteins involved in cancer cells migration/invasion, and supports its use as a therapeutic target in cancer prevention. Although higher concentrations of resveratrol $(\sim 100 \mu \mathrm{M})$ induces cell death in cancer cells [24], the current study suggest that lower physiologically relevant dose of resveratrol $(\sim 1 \mu \mathrm{M})$ prevent the migration and invasion of cancer cells from the primary site. Resveratrol has shown promising results for the treatment of many diseases using animal models [27] and recently findings have been extended to humans. For example, in a recent clinical trial, 30 days of resveratrol treatment $(150 \mathrm{mg} /$ day) induced beneficial metabolic changes in obese humans [54]. Rapid metabolism and poor bioavailability is generally thought to be a limiting factor in the use of resveratrol as a therapeutic agent in translational medicine. However, recent studies show that resveratrol sulfate, a metabolite of resveratrol is converted back into resveratrol inside the cells and the effective concentration of resveratrol inside the cells may be higher [55]. Since retinoic acid treatment increases TG2 protein level and resveratrol inhibits the migration of TG2expressing cells, this study also proposes the use of resveratrol with retinoic acid for the treatment of neuroblatoma.

\section{Additional file}

\section{Additional file 1: Supplementary Data.}

\section{Abbreviations}

BAPTA-AM: 1,2-Bis (2-aminophenoxy) ethane- $N, N, N^{\prime}, N^{\prime}$-tetraacetic acid tetrakis (acetoxymethyl ester); DMSO: Dimethyl sulphoxide; DTT: Dithiothreitol;
IOD: Integrated optical density; MDC: Monodensylcadavarine; PBS: Phosphate buffered saline; PMSF: Phenylmethylsulfonyl fluoride; res: Resveratrol;

TG2: Tissue-transglutaminase.

\section{Competing interest}

The authors declare that they have no competing interest.

\section{Authors' contributions}

AK and USS designed all experiments. AK performed experiments, KBW helped in $\mathrm{Ca}^{2+}$-related experiments, and $\mathrm{JH}$ conducted computational modeling. AK, HAL, DJD and USS analyzed the data and wrote the manuscript. All authors read and approved the final manuscript.

\section{Acknowledgements}

We thank to Dr. Gail V. W. Johnson (University of Rochester, New York) for providing the $\mathrm{SHY}_{\mathrm{TG} 2}, \mathrm{SHY}_{\text {vector }}$ and $\mathrm{SHY}$ mutant cells. We thank to Dr. Kapil Mehta (MD Anderson Cancer Center, Texas) for providing the pancreatic cancer cells.

\section{Grant support}

This research was supported by National Institutes of Health (Grant R21AA016121 to USS) and Health Sciences Distinguished Professorship (to DJD).

\section{Author details}

'Department of Pathology, Microbiology and Immunology, School of Medicine, University of South Carolina, Columbia, SC 29209, USA.

${ }^{2}$ Department of Computer Science and Engineering, University of South Carolina, Columbia, SC, USA. '3 Department of Cell Biology and Anatomy, School of Medicine, University of South Carolina, Columbia, SC, USA. ${ }^{4}$ Department of Pharmacology, Physiology and Neuroscience, School of Medicine, University of South Carolina, Columbia, SC, USA. ${ }^{5}$ Department of Internal Medicine, School of Medicine, University of South Carolina, Columbia, SC, USA.

Received: 9 September 2013 Accepted: 4 April 2014 Published: 11 April 2014

\section{References}

1. Folk JE, Finlayson JS: The epsilon-(gamma-glutamyl) lysine crosslink and the catalytic role of transglutaminases. Adv Protein Chem 1977, 31:1-133.

2. Lorand L, Graham RM: Transglutaminases: crosslinking enzymes with pleiotropic functions. Nat Rev Mol Cell Biol 2003, 4(2):140-156.

3. Singh US, Erickson JW, Cerione RA: Identification and biochemical characterization of an 80 kilodalton GTP-binding/transglutaminase from rabbit liver nuclei. Biochemistry 1995, 34(48):15863-15871.

4. Nakaoka H, Perez DM, Baek KJ, Das T, Husain A, Misono K, Im MJ, Graham RM: Gh: a GTP-binding protein with transglutaminase activity and receptor signaling function. Science 1994, 264(5165):1593-1596.

5. Begg GE, Carrington L, Stokes PH, Matthews JM, Wouters MA, Husain A, Lorand L, lismaa SE, Graham RM: Mechanism of allosteric regulation of transglutaminase 2 by GTP. Proc Natl Acad Sci U S A 2006, 103(52):19683-19688.

6. Telci D, Wang Z, Li X, Verderio EA, Humphries MJ, Baccarini M, Basaga H, Griffin M: Fibronectin-tissue transglutaminase matrix rescues RGD-impaired cell adhesion through syndecan-4 and beta1 integrin co-signaling. $\mathrm{J}$ Biol Chem 2008, 283(30):20937-20947.

7. Collighan RJ, Griffin M: Transglutaminase 2 cross-linking of matrix proteins: biological significance and medical applications. Amino Acids 2009, 36(4):659-670.

8. Akimov SS, Belkin AM: Cell-surface transglutaminase promotes fibronectin assembly via interaction with the gelatin-binding domain of fibronectin: a role in TGFbeta-dependent matrix deposition. J Cell Sci 2001, 114(Pt 16):2989-3000.

9. Balklava Z, Verderio E, Collighan R, Gross S, Adams J, Griffin M: Analysis of tissue transglutaminase function in the migration of Swiss 3 T3 fibroblasts: the active-state conformation of the enzyme does not affect cell motility but is important for its secretion. J Biol Chem 2002, 277(19):16567-16575.

10. Lin CY, Tsai PH, Kandaswami CC, Chang GD, Cheng CH, Huang CJ, Lee PP, Hwang JJ, Lee MT: Role of tissue transglutaminase 2 in the acquisition of 
a mesenchymal-like phenotype in highly invasive A431 tumor cells. Mol Cancer 2011, 10:87.

11. Mehta K, Kumar A, Kim HI: Transglutaminase 2: a multi-tasking protein in the complex circuitry of inflammation and cancer. Biochem Pharmacol 2010, 80(12):1921-1929.

12. Verma A, Wang $H$, Manavathi B, Fok JY, Mann AP, Kumar R, Mehta K Increased expression of tissue transglutaminase in pancreatic ductal adenocarcinoma and its implications in drug resistance and metastasis. Cancer Res 2006, 66(21):10525-10533.

13. Hwang JY, Mangala LS, Fok JY, Lin YG, Merritt WM, Spannuth WA, Nick AM, Fiterman DJ, Vivas-Mejia PE, Deavers MT, Coleman RL, Lopez-Berestein G, Mehta K, Sood AK: Clinical and biological significance of tissue transglutaminase in ovarian carcinoma. Cancer Res 2008, 68(14):5849-5858.

14. Satpathy M, Cao L, Pincheira R, Emerson R, Bigsby R, Nakshatri H, Matei D: Enhanced peritoneal ovarian tumor dissemination by tissue transglutaminase. Cancer Res 2007, 67(15):7194-7202.

15. Mangala LS, Fok JY, Zorrilla-Calancha IR, Verma A, Mehta K: Tissue transglutaminase expression promotes cell attachment, invasion and survival in breast cancer cells. Oncogene 2007, 26(17):2459-2470.

16. Fok JY, Ekmekcioglu S, Mehta K: Implications of tissue transglutaminase expression in malignant melanoma. Mol Cancer Ther 2006, 5(6):1493-1503.

17. Shao M, Cao L, Shen C, Satpathy M, Chelladurai B, Bigsby RM, Nakshatri H, Matei D: Epithelial-to-mesenchymal transition and ovarian tumor progression induced by tissue transglutaminase. Cancer Res 2009, 69(24):9192-9201.

18. Kumar A, Xu J, Brady S, Gao H, Yu D, Reuben J, Mehta K: Tissue transglutaminase promotes drug resistance and invasion by inducing mesenchymal transition in mammary epithelial cells. PLoS One 2010, 5(10):e13390.

19. Verma A, Guha S, Diagaradjane P, Kunnumakkara AB, Sanguino AM, LopezBerestein G, Sood AK, Aggarwal BB, Krishnan S, Gelovani JG, Mehta K: Therapeutic significance of elevated tissue transglutaminase expression in pancreatic cancer. Clin Cancer Res 2008, 14(8):2476-2483.

20. Antonyak MA, Li B, Regan AD, Feng Q, Dusaban SS, Cerione RA: Tissue transglutaminase is an essential participant in the epidermal growth factor-stimulated signaling pathway leading to cancer cell migration and invasion. J Biol Chem 2009, 284(27):17914-17925.

21. Singh US, Pan J, Kao YL, Joshi S, Young KL, Baker KM: Tissue Transglutaminase Mediates Activation of RhoA and MAP Kinase Pathways during Retinoic Acid-induced Neuronal Differentiation of SH-SY5Y Cells. J Biol Chem 2003, 278(1):391-399.

22. Singh US, Kunar MT, Kao YL, Baker KM: Role of transglutaminase II in retinoic acid-induced activation of RhoA- associated kinase-2. EMBO J 2001, 20(10):2413-2423.

23. Roy SK, Chen Q, Fu J, Shankar S, Srivastava RK: Resveratrol inhibits growth of orthotopic pancreatic tumors through activation of FOXO transcription factors. PLoS One 2011, 6(9):e25166.

24. van Ginkel PR, Sareen D, Subramanian L, Walker Q, Darjatmoko SR, Lindstrom MJ, Kulkarni A, Albert DM, Polans AS: Resveratrol inhibits tumor growth of human neuroblastoma and mediates apoptosis by directly targeting mitochondria. Clin Cancer Res 2007, 13(17):5162-5169.

25. Bishayee $\mathrm{A}$ : Cancer prevention and treatment with resveratrol: from rodent studies to clinical trials. Cancer Prev Res (Phila) 2009, 2(5):409-418.

26. Chen Y, Tseng SH, Lai HS, Chen WJ: Resveratrol-induced cellular apoptosis and cell cycle arrest in neuroblastoma cells and antitumor effects on neuroblastoma in mice. Surgery 2004, 136(1):57-66.

27. Pervaiz S, Holme AL: Resveratrol: its biologic targets and functional activity. Antioxid Redox Signal 2009, 11(11):2851-2897.

28. Joshi S, Guleria R, Pan J, DiPette D, Singh US: Retinoic acid receptors and tissue-transglutaminase mediate short-term effect of retinoic acid on migration and invasion of neuroblastoma SH-SY5Y cells. Oncogene 2006, 25(2):240-247.

29. Kumar A, Singh CK, DiPette DD, Singh US: Ethanol impairs activation of retinoic acid receptors in cerebellar granule cells in a rodent model of fetal alcohol spectrum disorders. Alcohol Clin Exp Res 2010, 34(5):928-937.

30. Kumar A, Singh CK, Lavoie HA, Dipette DJ, Singh US: Resveratrol restores Nrf2 level and prevents ethanol-induced toxic effects in the cerebellum of a rodent model of fetal alcohol spectrum disorders. Mol Pharmacol 2011, 80(3):446-457.

31. Singh US, Cerione RA: Biochemical effects of retinoic acid on GTP-binding Protein/Transglutaminases in HeLa cells. Stimulation of GTP-binding and transglutaminase activity, membrane association, and phosphatidylinositol lipid turnover. J Biol Chem 1996, 271(44):27292-27298.
32. Tucholski J, Lesort M, Johnson GV: Tissue transglutaminase is essential for neurite outgrowth in human neuroblastoma SH-SY5Y cells. Neuroscience 2001, 102(2):481-491.

33. Mishra S, Murphy LJ: Tissue transglutaminase has intrinsic kinase activity: identification of transglutaminase 2 as an insulin-like growth factorbinding protein-3 kinase. J Biol Chem 2004, 279(23):23863-23868.

34. Pinkas DM, Strop P, Brunger AT, Khosla C: Transglutaminase 2 undergoes a large conformational change upon activation. PLoS Biol 2007, 5(12):e327.

35. Park SJ, Ahmad F, Philp A, Baar K, Williams T, Luo H, Ke H, Rehmann H, Taussig R, Brown AL, Kim MK, Beaven MA, Burgin AB, Manganiello V, Chung $\mathrm{JH}$ : Resveratrol ameliorates aging-related metabolic phenotypes by inhibiting CAMP phosphodiesterases. Cell 2012, 148(3):421-433.

36. Mi LY, Ettenson DS, Edelman ER: Phospholipase C-delta extends intercellular signalling range and responses to injury-released growth factors in nonexcitable cells. Cell Prolif 2008, 41(4):671-690.

37. Padin JF, de Diego AM, Fernandez-Morales JC, Merino C, Maroto M, CalvoGallardo E, Arranz JA, Yanez M, Garcia AG: Resveratrol augments nitric oxide generation and causes store calcium release in chromaffin cells. Eur J Pharmacol 2012, 685(1-3):99-107.

38. Stamnaes J, Pinkas DM, Fleckenstein B, Khosla C, Sollid LM: Redox regulation of transglutaminase 2 activity. J Biol Chem 2010, 285(33):25402-25409.

39. Kiraly R, Csosz E, Kurtan T, Antus S, Szigeti K, Simon-Vecsei Z, Korponay-Szabo IR, Keresztessy Z, Fesus L: Functional significance of five noncanonical $\mathrm{Ca} 2+-$ binding sites of human transglutaminase 2 characterized by site-directed mutagenesis. FEBS J 2009, 276(23):7083-7096.

40. Bergamini CM: GTP modulates calcium binding and cation-induced conformational changes in erythrocyte transglutaminase. FEBS Lett 1988, 239(2):255-258.

41. Kiraly $R$, Demeny M, Fesus L: Protein transamidation by transglutaminase 2 in cells: a disputed $\mathrm{Ca} 2+-$ dependent action of a multifunctional protein. FEBS J 2011, 278(24):4717-4739.

42. Liu S, Cerione RA, Clardy J: Structural basis for the guanine nucleotidebinding activity of tissue transglutaminase and its regulation of transamidation activity. Proc Natl Acad Sci U S A 2002, 99(5):2743-2747.

43. Di Venere A, Rossi A, De Matteis F, Rosato N, Agro AF, Mei G: Opposite effects of $\mathrm{Ca}(2+)$ and GTP binding on tissue transglutaminase tertiary structure. J Biol Chem 2000, 275(6):3915-3921.

44. Casadio R, Polverini E, Mariani P, Spinozzi F, Carsughi F, Fontana A, Polverino de Laureto P, Matteucci G, Bergamini CM: The structural basis for the regulation of tissue transglutaminase by calcium ions. Eur J Biochem 1999, 262(3):672-679.

45. Boroughs LK, Antonyak MA, Johnson JL, Cerione RA: A unique role for heat shock protein 70 and its binding partner tissue transglutaminase in cancer cell migration. J Biol Chem 2011, 286(43):37094-37107.

46. Lai TS, Davies C, Greenberg CS: Human tissue transglutaminase is inhibited by pharmacologic and chemical acetylation. Protein Sci 2010, 19(2):229-235.

47. Jeong EM, Kim CW, Cho SY, Jang GY, Shin DM, Jeon JH, Kim IG: Degradation of transglutaminase 2 by calcium-mediated ubiquitination responding to high oxidative stress. FEBS Lett 2009, 583(4):648-654.

48. Park D, Choi SS, Ha KS: Transglutaminase 2: a multi-functional protein in multiple subcellular compartments. Amino Acids 2010, 39(3):619-631.

49. Belkin AM, Tsurupa G, Zemskov E, Veklich Y, Weisel JW, Medved L: Transglutaminase-mediated oligomerization of the fibrin (ogen) alphaC domains promotes integrin-dependent cell adhesion and signaling. Blood 2005, 105(9):3561-3568.

50. Satpathy M, Shao M, Emerson R, Donner DB, Matei D: Tissue transglutaminase regulates matrix metalloproteinase-2 in ovarian cancer by modulating cAMP-response element-binding protein activity. J Biol Chem 2009, 284(23):15390-15399.

51. Deryugina El, Quigley JP: Matrix metalloproteinases and tumor metastasis. Cancer Metastasis Rev 2006, 25(1):9-34.

52. Borra MT, Smith BC, Denu JM: Mechanism of human SIRT1 activation by resveratrol. J Biol Chem 2005, 280(17):17187-17195.

53. Wang Z, Griffin M: The role of TG2 in regulating S100A4-mediated mammary tumour cell migration. PLoS One 2013, 8(3):e57017.

54. Timmers $\mathrm{S}$, Konings $\mathrm{E}$, Bilet $\mathrm{L}$, Houtkooper $\mathrm{RH}$, van de Weijer $\mathrm{T}$, Goossens GH, Hoeks J, van der Krieken S, Ryu D, Kersten S, Moonen-Kornips E, Hesselink MK, Kunz I, Schrauwen-Hinderling VB, Blaak EE, Auwerx J, Schrauwen P: Calorie restriction-like effects of 30 days of resveratrol 
supplementation on energy metabolism and metabolic profile in obese humans. Cell Metab 2011, 14(5):612-622.

55. Patel KR, Andreadi C, Britton RG, Horner-Glister E, Karmokar A, Sale S, Brown VA, Brenner DE, Singh R, Steward WP, Gescher AJ, Brown K: Sulfate metabolites provide an intracellular pool for resveratrol generation and induce autophagy with senescence. Sci Transl Med 2013, 5(205):205ra133.

doi:10.1186/1471-2407-14-256

Cite this article as: Kumar et al: Conformational changes and

translocation of tissue-transglutaminase to the plasma membranes: role in cancer cell migration. BMC Cancer 2014 14:256.

\section{Submit your next manuscript to BioMed Central and take full advantage of:}

- Convenient online submission

- Thorough peer review

- No space constraints or color figure charges

- Immediate publication on acceptance

- Inclusion in PubMed, CAS, Scopus and Google Scholar

- Research which is freely available for redistribution 